\title{
Human Model for Studying the Bare Area of the Liver with Special Reference to the Metastatic Potential of Lung Cancer Metastases
}

\author{
Wilson I B Onuigbo* \\ Medical Foundation \& Clinic, Nigeria
}

Submission: December 17, 2015; Published: January 27, 2016

*Corresponding author: Wilson I B Onuigbo, Medical Foundation \& Clinic, 8 Nsukka Lane, Enugu, 400001 Nigeria, Tel: 234-803-720-8680; Email: wilson.onuigbo@gmail.com

\begin{abstract}
The medical masters of yester years noted the great importance of the actions of Nature in their writings. For instance, Julius Cohnheim was emphatic that autopsies "are all in a manner experiments instituted by nature, which we need only rightly interpret to get a clear idea of the causes, laws of growth, and significance of the tumour." Indeed, as Nature has it, there is a "bare" area of the liver. Moreover, this area is adjacent to the right adrenal gland. Furthermore, as Bourne depicted, the position of the adrenal gland is probably not fortuitous but related to some evolutionary factor. Therefore, in line with my other practical papers, it is hypothesized that, in cases of right lung cancer, a block containing hepatic and adrenal deposits should be obtained. Then, special staining of the individual lymphatic and blood vessels should be carried out. In all probability, this process will reveal the routes of spread, especially with reference to the interconnections of the individual metastases present in both the liver and the adrenal gland. In other words, the metastatic patterns will confirm or confute the concept of the potentiality of hepatic metastasis in terms of being able to progress further to the adrenal gland.
\end{abstract}

Keywords: Cancer model, lung, liver, adrenal, metastases, Interconnections

\section{Introduction}

Recently, in a wide-ranging review [1], I documented the views of notable medical masters whose vintages were 1847, 1870, 1889, and 1897. To exemplify, Julius Conheim [2] was coherent. In his own words, autopsies "are all in a manner experiments instituted by nature, which we need only rightly interpret to get a clear idea of the causes, laws of growth, and significance of the growth."

Growth of the liver type occupies a special niche because that organ possesses the anatomically distinct "bare area" [3]. Moreover, the right adrenal gland is adjacent to this particular area. Furthermore, as Bourne surmised [4], the adrenal gland's position in the human body is probably not fortuitous but related to some evolutionary factor.
Factor of anatomical dimension is the method of performing the autopsy. On this account, I instituted the mono-block formalin-fixation method [5]. This method perfected the procurement of nicely interconnected tissues from the neck to the pelvis. See For instance, it was on this account that my paper on the pancreas was succinct in that: its invasion by lung cancer "is due not to mere direct extension but to discontinuous true lymphatic metastasis"[6]. In fact, as I added, "This result demonstrates the value of reconsidering the ways in which lymphatic spread of cancer may occur."

\section{Hypothesis}

In the 1970s, there was considerable interest in the possibility of the one metastasis producing another metastasis. Thus, Hoover and Ketcham [7], who entitled 
their paper "metastasis of metastases," demonstrated it in experimental animals. Next, Roth's associates [8] documented at operation the "known metastases originating from other metastatic foci." Other investigators came to the same opinion about this form of metastasis $[9,10]$.

Metastasis was studied elsewhere with special reference to the cases of cancers adjacent to the skull and brain [11]. There was also the paper in which the large expanse of tissues between the stomach and the ovary was examined for the presence of lymphatic pathways [12]. It is in this manner that I am persuaded that, in cases of right lung cancer, a block containing both the bare hepatic area and its adrenal metastatic counterpart should be obtained. Thereafter, the now available special staining technique should be used to differentiate between any utilized lymphatic vessels or blood vessels. In other words, the metastatic potential of metastases will, in all probability, automatically manifest their possible roles in the important right lung-liver-adrenal axis.

\section{Conclusion}

Nature has so anatomically arranged the bare area of the liver and the contacting adrenal gland that the new special staining technique [13] will clarify the interconnecting positions, i.e., the invading cancer cells cannot but give clear evidence of their respective foot steps. Such pathways are best delineated during lymphatic permeation. This will no doubt confirm or confute the theory of metastases producing their own individual metastasis. Incidentally, as regards the adrenal gland per se, its selectivity during metastasis has been traced to lymphangiogenesis [14]. Perhaps, this applies also to the intervening liver or to sequential combination of both the liver and the adrenal gland.

\section{References}

1. Onuigbo WIB (2015) The visionary views of medical masters of yester years on nature's norms point to present prospects in the target therapy of cancer. Biology \& Medicine (Aligarh) 7: 221.

2. Conheim J (1889) Lectures on general pathology. Section I. London: The New Sydenham Society 14.

3. Lim JH, Auh YH, Suh SJ, Ki WK (1990) Right perirenal space computed tomography evidence of communication between the bare area of the liver. Clinical Imaging 14(3): 239-244.

4. Bourne GH (1949) The mammalian adrenal gland, London: Oxford University Press 75(2): 185-186.

5. Onuigbo WIB (1963) A mono-block formalin-fixation method for investigating cancer metastasis. Zeitschrift fur Krebsforschung, 65(3): 209-210.

6. Onuigbo WIB (1966) Lung cancer metastasis to the pancreas and its surrounding nodes. British Journal of Diseases of the Chest $60(3)$ : 152-155.

7. Hoover HC Jr, Ketcham AS (1975) Metastasis of metastases. American Journal of Surgery 130(4): 405-411.

8. Roths JA, Silverstein MJ, Morton DL (1976) Metastatic potential of metastases. Surgery 79: 669-673.

9. Sugarbaker EV, Cohen AM, Ketcham AS (1971) Do metastases metastasize? Annals of Surgery 174(2): 161.

10. Ketcham AS, Wexler H and Clagett OT (1973) The metastatic potential of experimental pulmonary metastases. Journal of Surgical Research 15(1): 45-52.

11. Onuigbo WIB (2013) New hypothesis concerning cancer carriage with special reference to intracranial lymphatic connection. In Hypotheses in Clinical Medicine. In: Shoja MM, et al. (Eds.), Nova Science Publishers, New York, USA, pp. 167-180.

12. Onuigbo WIB (2010) The popliteal lymph node group as a naturally positioned model for research on lung cancer metastasis. Journal of Cancer Research and Experimental Oncology 2(3): 27-28.

13. Mohammed RA, Martin SG, Gill MS, Green AR, Paish EC, et al (2007) Improved methods of detection of lymphovascular invasion demonstrate that it is the predominant method of vascular invasion in breast cancer and has important clinical consequences. Am J Surg Pathol 31(12): 1825-1873.

14. Onuigbo WIB (1973) Cancer permeation: Processes, problems and prospects - a review. Cancer Research 33: 633-636.

15. Onuigbo WIB (2010) Lymphangiogenesis may explain adrenal selectivity in lung cancer metastases. Medical Hypotheses 75(2): 185-186. 